\title{
SAW デバイス腐食センサー
}

本田

卓*

1. は じめに

腐食現象を, 現象が生じているその場 (in situ)かつそ の時間内 (in real time) で測定することが，その現象を理 解するらえで重要であることは論をまたない。この要求 を満たすものとしては, 電気化学的方法が研究や実装置 のモニタリングに幅広く用いられている。しかし，この 方法も適用できる環境や検出感度に制約があり，相補的 な他の技術の開発が望まれている。ここに紹介する SAW (surface acoustic wave) デバイスを応用した方法 もその一つとして注目される。

SAW デバイスは弾性表面波を利用する素子で，一般 には高周波のフィルターや共振子として通信機などに用 いられている，これを腐食センサーに応用しようとする 試みがある，ところで，同じよらに超音波をプローブと して用いたものに水晶振動子を利用した QCM (quartz crystal microbalance) 法がある.これは水晶振動子の周 波数が電極の微重量変化に対応して変化するといら原理 に基づいて扣り，電極材料が腐食によって質量変化する 過程をモニターしょらとする方法である。この方法は， 近年, 広く検討されており, $5 \mathrm{MHz}$ の ATカッ卜水晶 を用いると，その検出感度は $1.1 \times 10^{-4} \mathrm{~g} / \mathrm{m}^{2(1)}$ と言わ れている。こうした超音波を利用する方法は，概ね用い られる波の周波数が高い汪ど感度も上がる. したがっ て, 数百 $\mathrm{MHz}$ 領域の波を用いる $\mathrm{SAW}$ デバイスは高感 度センサーとして期待がもたれる。また，後述するよら に，気相のみならず液相での使用も可能になってきてお り，適用領域も広がりをみせている。ここでは SAW デ バイス腐食センサーの動作原理と研究例に触れ，その将 来性に言及したい。

\section{2. 動 作 原 理}

図 1 はSAW デバイス腐食センサーの構造の一例であ る.圧電基板上に形成されたくし状電極(IDT : inter-

* (株)日立製作所日立研究所主任研究員

SAW Device Corrosion Sensors; Takashi Honda (Hitachi Research Laboratory, Hitachi, Ltd., Hitachi) Keywords: surface acoustic wave device, corrosion, sensor, monitoring, frequency 1990年 3 月 28 日受理

日本金属学会会報 第29巻 第 8 号 $(1990)$

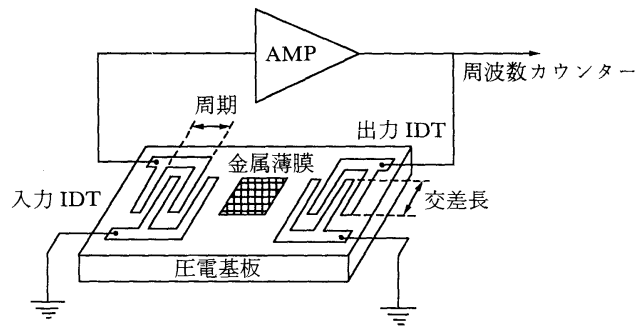

図 1 SAW デバイス腐食センサーの一例.

digital transducer)に電気信号を付加すると, 基板表面 に歪が生じ, その歪が他方の電極に伝わって再び電気信 号として取り出される. この基板表面を伝わる弾性表面 波の伝搬速度は伝搬面の弾性的性質を敏感に反映する。 SAW デバイス腐食センサーはこの特性を利用してい る.

$\mathrm{SAW}$ デバイスの共振周波数 $f$ は表面波の伝搬速度を $v$, IDT の周期を $d$ とすると，式（1)で与えられ，

$$
f=v / d
$$

$v$ が大きい汪ど，あるいは $d$ が小さいほど高い周波数が 得られる.

また，IDT 間の表面波伝搬面上に薄膜を形成した場 合，共振周波数の变化 $\Delta f$ は式 $(2)$ のように表すことが できる(2).

$$
\begin{aligned}
\Delta f= & \left(k_{1}+k_{2}\right) f^{2} h \rho-k_{2} f^{2} h\left(4 \mu / v^{2}\right) \\
& \times((\lambda+\mu) /(\lambda+2 \mu))
\end{aligned}
$$

ここに, $f$ 㧊よび $v$ はそれぞれ膜が形成されていないと きの周波数扣よび表面波速度， $k_{1}, k_{2}$ は圧電基板の材料 定数, $h$ および $\rho$ は薄膜の膜厚および密度， $\mu, \lambda$ はラメ の定数である．また，通常，第 2 項は無視できること から，この式は次のように単純化される.

$$
\Delta f=\left(k_{1}+k_{2}\right) f^{2} h \rho
$$

式 $(3)$ は $\Delta f$ が膜の質量に比例し, 検出感度が $f$ の 2 乗 に比例して高くなることを示している。 したがって，高 周波の SAW デバイスを用いれば，IDT 間に形成した 薄膜の腐食にともなら質量変化を高感度にモニターする ことが可能と考えられる.

\section{3. 気相腐食への適用}

市販の SAW デバイスは気相で用いられるのが常であ 
る。したがって，腐食センサーとしても気相で用いる方 が容易である。

Martine ら ${ }^{(3)}$ は ST カット水晶圧電基板 $(23 \mathrm{~mm} \times 8$ $\mathrm{mm} \times 0.8 \mathrm{~mm})$ の中央に銅薄膜 $(<2 \mu \mathrm{m})$ を蒸着したセン サ一を種々の腐食系で検討している. IDT (周期 $32 \mu \mathrm{m}$, 対数50)はそれ自体の腐食を抑えるため， Cr 上に $\mathrm{Au}$ を 蒸着してあり，97 MHzで共振する Rayleigh 波をモニ タ一用の波として用いている。このセンサーを $\mathrm{H}_{2} \mathrm{~S}$ を $5 \mathrm{ppm}$ 含毛乾燥 $\mathrm{N}_{2}\left(299.8 \mathrm{~K}\left(26.6^{\circ} \mathrm{C}\right)\right)$ 中に置いたところ, $23 \mathrm{ppm} の$ 周波数変化を生じた。この变化は $1.8 \times 10^{-3}$ $\mathrm{g} / \mathrm{m}^{2}$ の質量増加に相当し, $\mathrm{Cu}_{2} \mathrm{~S}$ とて 4 単分子層( $1.5 \mathrm{~nm})$ 形成したことになると報告している。ささら， この結果から 1 単分子檿を検出することもできるとみ ている。また，ベンゾトリアゾール(BTA)の腐食抑制 効果についても検討している(4). 図 2 はBTA 処理と未 処理の $\mathrm{Cu} \mathrm{H}_{2} \mathrm{~S}$ と $\mathrm{NO}_{2}$ を含导湿潤 $\mathrm{N}_{2}(313 \mathrm{~K})$ 中で腐 食させた場合の周波数変化を比較したものである。未処 理の Cu は約 $720 \mathrm{ks}(200 \mathrm{~h})$ で周波数が $500 \mathrm{ppm}$ ほど負 側に変化して扣り，Cuの腐食により質量が増加したこ 之を示している。この変化量は質量換算すると， $40 \times$ $10^{-3} \mathrm{~g} / \mathrm{m}^{2}$ 江相当する。一方, BTA 処理を施した $\mathrm{Cu}$ の質量変化は $2.8 \times 10^{-3} \mathrm{~g} / \mathrm{m}^{2}$ で, BTAによる腐食抑 制効果が顕著である。

こうした結果は, 従来, 長期の暴露試験や昇温などに より加速された条件でしか評価し得なかった気相におけ る微量の腐食をin situかつ in real time で検出できるこ とを示唆して扣り，この分野の有力な研究手段になるも のと期待される。

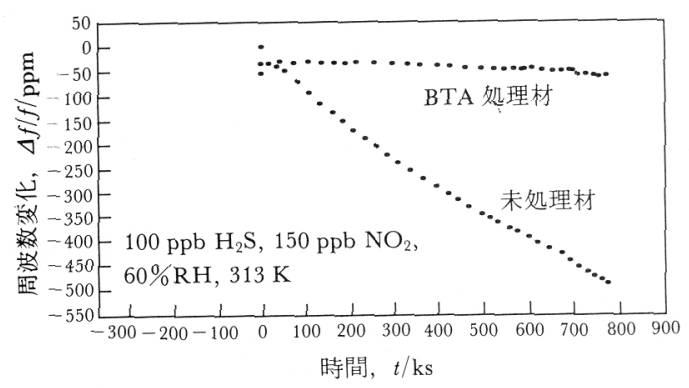

図 2 気相腐食の測定例 ${ }^{(4)}$.

\section{4. 液相腐食への適用}

水晶振動子と同様に, SAW デバイスを液相で用いよ らとする試みがある。表面波として最も一般的な Rayleigh 波は，基板表面の伝搬方向への横波放射之表 面に垂直方向への縦波放射の 2 つ粒子変位をもつ. この波は液中に打いて固/液界面を伝搬する際に, 液中 に縦波を放射してェネルギーが減衰してしまうことか
ら，液中で使用することは難しい。しかし，綐波放射を しないタイプのSH 波(shear horizontal wave)は表面へ のパワー集中度が高いため, 液中で減衰せずに伝搬する 特性をもっている.

筆者ら は $\mathrm{LiTaO}_{3}\left(36^{\circ}\right.$ 回転 $\mathrm{Y}$ カット $\mathrm{X}$ 伝搬) を基板に 用い, 交差長 $2 \mathrm{~mm}$, 周期 $40 \mu \mathrm{m}$, 対数 $150 \mathrm{IDT}(\mathrm{Au} /$ Cr)をもつSAW デバイスを試作した. IDT間の表面波 伝搬面上には約 $100 \mathrm{~nm}$ 厚の Al $2 \mathrm{~mm} \times 5 \mathrm{~mm}$ 亿真空 蒸着した。図 3 性試作したセンサーとこれを組み达んだ 腐食反応セルである。このセルには腐食測定用センサー のほかに, 同一のSAWデバイスを温度補償用として組 み込んである。七ルにはAI 薄膜部分のみが露出するよ らに空を開け，これ以外の部分はシリコンゴムで覆い， アクリル板をから゙せて固定した。図4 は測定系で, 1 対 のSAW デバイスセンサーと発振回路, 周波数カウンタ 一およびパーソナルコンピューターより構成される. 図 5 は実験装置である。腐食にともなら周波数変化は1 対のセンサーの周波数の差分として連続測定される。こ 机は $\mathrm{LiTaO}_{3}$ の温度変化による周波数変化を補償し, 腐 食にともなら真の周波数変化分のみを取り出すためであ る.

図 6 は $\mathrm{Al}$ 薄膜の $1 \mathrm{kmol} \cdot \mathrm{m}^{-3} \mathrm{HCl}$ 水溶液中での溶解 にともなら周波数変化 $\Delta f$ を $303 \mathrm{~K}$ で測定した結果であ る. Af は約 $3000 \mathrm{~s}$ 経過後に匡注一定になり, その総変 化量は正側に $15.038 \mathrm{kHz}$ であった。一方, 実験終了後 の溶液分析から $1.3 \mu \mathrm{g}$ の $\mathrm{Al}$ が溶出していた。これらの 結果から，A1の溶解速度は $9.6 \times 10^{-5} \mathrm{~g} \cdot \mathrm{m}^{-2} \cdot \mathrm{s}^{-1}$ で, このセンサーの検出感度は $2 \times 10^{-5} \mathrm{~g} / \mathrm{m}^{2}$ と非常に高い ことがわかった。

Sorensenら (4) 恃気相腐食で使用したものと同じST カット水晶のセンサーを液相で検討している，気相では $97 \mathrm{MHz}$ の Rayleigh 波を用いたが，液相ではこの波は 減衰するため $158 \mathrm{MHz}$ の $\mathrm{SH}$ 波を用いた。腐食反応セ ルの構造は筆者らのものとは異なり, 図7のよらに薄膜 上に $100 \mathrm{~mm}^{3}$ 程度の液が入れられる構造となっている。 このセルを用いて， $0.3 \% \mathrm{NaOH}(298 \mathrm{~K})$ 中での $\mathrm{Al}$ 薄膜 の腐食を $8 \times 10^{-5} \mathrm{~g} / \mathrm{m}^{2}$ の感度で測定できたと報告して

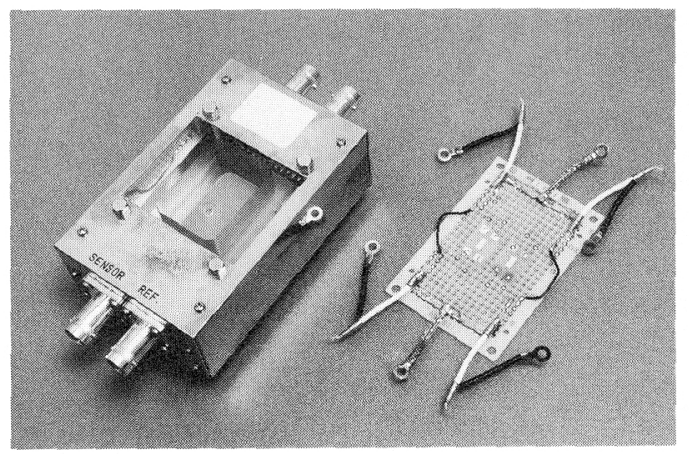

図 $3 \mathrm{SAW}$ デバイス腐食センサーと腐食反応セル。 


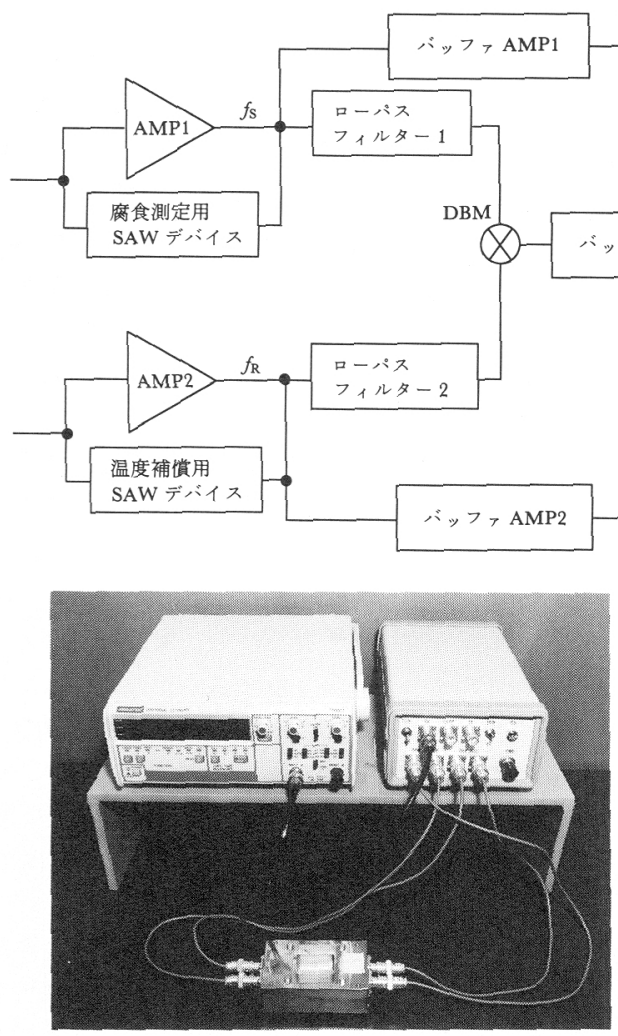

図 5 液相腐食の測定構成.

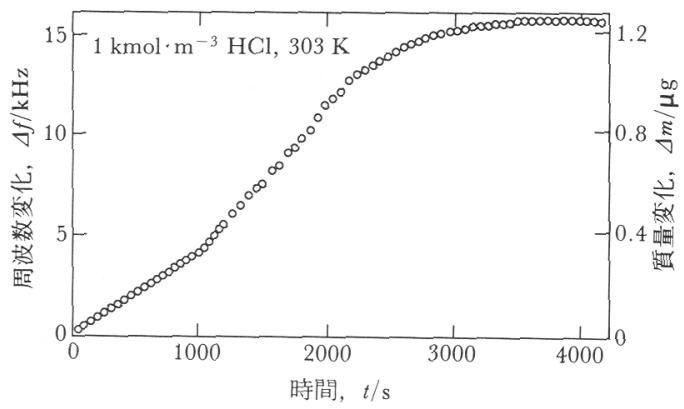

図 $6 \mathrm{HCl}$ 水溶液中に批居 $\mathrm{Al}$ 薄膜腐食の測定結果.

いる、また, $\mathrm{Cu} の$ 無電解めっき(5), $\mathrm{Pd}$ 電極への $\mathrm{Ag} の$ 電析挙動(6)などについても検討している.

$\mathrm{SAW}$ デバイスを溶液系センサーとして適用する試み は歷史的に浅いが, 塩川ら ${ }^{(7)}$ にって理論的な解析も進 んでおり, 今後の発馓が期待される。

\section{5. おわりに}

超音波をプローブとした腐食センサーとして, SAW デバイスを応用したセンサーについて概説した、SAW デバイスをセンサーに応用すること自体, 歴史的に浅 く, まして腐食への適用が検討されたのはここ数年のこ

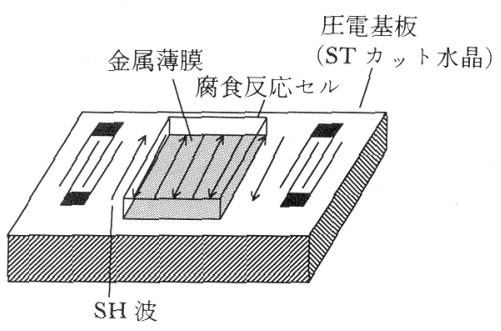

図 7 液相腐食測定用 SAW デバイスセンサーの 一例 ${ }^{(4)}$.

とである。しかし，動作特性に関する理論検討も進んで おり，気液いずれの系にも適用ができ，しかも $\mathrm{ng}$ とい ら微量な腐食を検出しらる可能性のあることは非常に魅 力的である。腐食研究に限っても, 不働態化, 大気腐食 など重要な現象理解に役立つ期待がもたれる。しかし， 一方では，孔食などの局部腐食や溶出と酸化皮膜形成が 同時に生じる場合にも解析が可能であるかどうか不明な 点も多い、今後, SAW デバイスセンサーが多方面で検 討され，理論，実験両面で発展することを切に望むしだ いである。

稿を終わるに当り，実験を担当していただいた新井 祐子氏に深謝したい。

\section{文献}

(1) J. H. Thomas, III and S. P. Sharma: J. Vic. Sci., $13(1976), 549$.

( 2 ) H. Wohltijen, A. Snow and D. Ballantine: TRANSDUCERS '85, IEEE, (1985), 66.

( 3 ) S. J. Martine, A. J. Ricco and N. R. Sorensen: Proc. Electrochem. Soc., (1987), 50.

(4) N. R. Sorensen, A. J. Ricco and S. J. Martine: CORROSION '89, Paper 27, NACE, (1989).

( 5 ) A. J. Ricco and S. J. Martine: Proc. Electrochem. Soc., (1987), 711.

(6) A. J. Ricco and S. J. Martine: Proc. Electrochem. Soc., (1987), 501.

（7）塩川祥子, 桑原正和, 森泉豊栄：信学技報, US8844, (1988), 13. 